\title{
The Experimental Study Of Wekondo Materialsplite And Sand Of Poni-Poniki District Tirawuta East Kolaka Regency As Material Of Concrete Making
}

\author{
Mansyur \\ University of Sembilanbelas November Kolaka \\ mansyurusn14@gmail.com
}

\begin{abstract}
Received : $\quad$ May 10, 2017
Accepted

August 13, 2017

ABSTRACT

Split Material derived from Wekondo and Sand found in Poni-Poniki is an abundant material that has the potential to be used as a material for making concrete. The purpose of this research is to find out whether Wekondo split material and Poni-poniki sand can be used in making concrete both in terms of material characteristics and the quality of concrete achieved. This research is experimental by testing material characteristics as well as the making of $150 \mathrm{~mm}$ sized concrete cube test object on applicable SNI. The result of the test of the characteristic of Split material such as filter analysis at \# $3 / 8$ exceeds the specification of $6.25 \%$, aggregate wear $19,639 \%$, pass filter sieve \# 200 is $0.772 \%$, specific gravity (SSD) $2,913 \mathrm{gr} / \mathrm{cm} 3,1.363 \%$, $0.628 \%$ moisture content of $1.7 \mathrm{~kg} / \mathrm{Itr}$ solid content and $1.469 \mathrm{~kg} / \mathrm{Itr}$ of loose fill weight. While the examination of a sand material of Poni-poniki analyzed sieve all meet the standard specification, pass filter sieve \# 200 is $1,680 \%$, density of $2.661 \mathrm{gr} / \mathrm{cm} 3$, aggregate $1.647 \%$, moisture content $0.580 \%$, / Itr the loose weight of $1.531 \mathrm{~kg} /$ Itr. While in concrete compressive strength test, the age of 7 days is $203,68 \mathrm{~kg} / \mathrm{cm} 2$, and age 28 day is $257,55 \mathrm{~kg} / \mathrm{cm} 2$. From the results of the study showed that the compressive strength at the age of 28 days can achieve K250 quality.
\end{abstract}

(C) 2017 Published By IJTI. This is an Open Acces article under the CC BY SA License https://creativecommons.org/licenses/by-sa/4.0/

Keyword : Material Characteristics and Concrete Quality

\section{INTRODUCTION}

Implementation of construction in developing areas, especially the district of East Kolaka, requires the availability of natural materials to support infrastructure development, so as to produce economic buildings. One of the most economical construction materials used in the area is concrete because its constituent material is still available around the local area. But in essence, the manufacture of concrete must be through the mechanism of testing the constituent materials. The constituent material consists of a cemented cement material, coarse aggregate, fine aggregate, water and additives (admixture or additive). Concrete also has several advantages over other construction materials, such as having a large compressive strength, fire resistance, easy to form, no special skills required in the manufacture, and raw materials easy to obtain, so that the concrete is superior in terms of cost.

Concrete materials are very easy to find anywhere, whether sand or rock split almost every region has it, but not all sand and crushed stone can be used to make concrete with a great quality/strength. Therefore, it is necessary to research the material of the concrete material before making concrete for concrete construction. In general, the aggregate is the largest material of about $70 \%-75 \%$ of concrete filler, it is very important because the material is very influential on the quality of concrete, (Kardiyono, 1992).

In this research will be used split material from Wekondo Village where this area there are many mountain stones of various sizes. Usually used by the community to make the foundation of the house and others. While the sand studied large from the river Poni-poniki 
located in District Tirawuta East Kolaka regency as a mixture of concrete. The purpose of this study is to determine whether the material is feasible or not to be used as a material for the manufacture of concrete.

\section{MATERI ALS AND METHODS}

This research was conducted at UPTD Laboratory of Public Works Department of Southeast Sulawesi Province by using experimental method, namely testing of Split and sand characteristics and concrete compressive strength test at age 7 and 28 days referring to SNI 1974-2011. The compressive strength formula is given by $\sigma=\mathrm{P} / \mathrm{A}$, with $\mathrm{P}=$ Maximum load, and $\mathrm{A}=$ the surface area of the cube concrete.

Materials and equipment used in the manufacture of cube concrete are Portland cement composite brand Tonasa, Split (broken stone) from Wekondo Village and sand from Poni-Poniki River of Tirawuta District. Equipment that uses 1500 kN capacity test machine, $150 \mathrm{~mm}$ sized cube mould, concrete mixing machine/mixer, scope, bucket, balance sheet and other ancillary equipment.

This research was conducted for 28 days in the laboratory with two types of cube concrete items made, namely 4 pieces of 7 days old concrete and 4 cubes 28 days cube. From the water-cement factor of 0.55 gives the composition of cement concrete design mix 8 samples with the proportion of $6,584 \mathrm{Kg}$ of water, $11.97 \mathrm{Kg}$ of cement, $25,089 \mathrm{Kg}$ of sand and $30,764 \mathrm{Kg}$ split

\section{RESEARCH RESULT}

a. Testing of Aggregate Sieve Analysis

The results of Split filter analysis from Wekondo Village can be presented in the explanation below.

Table 1. Wekondo Split Test Analysis Test Re sult

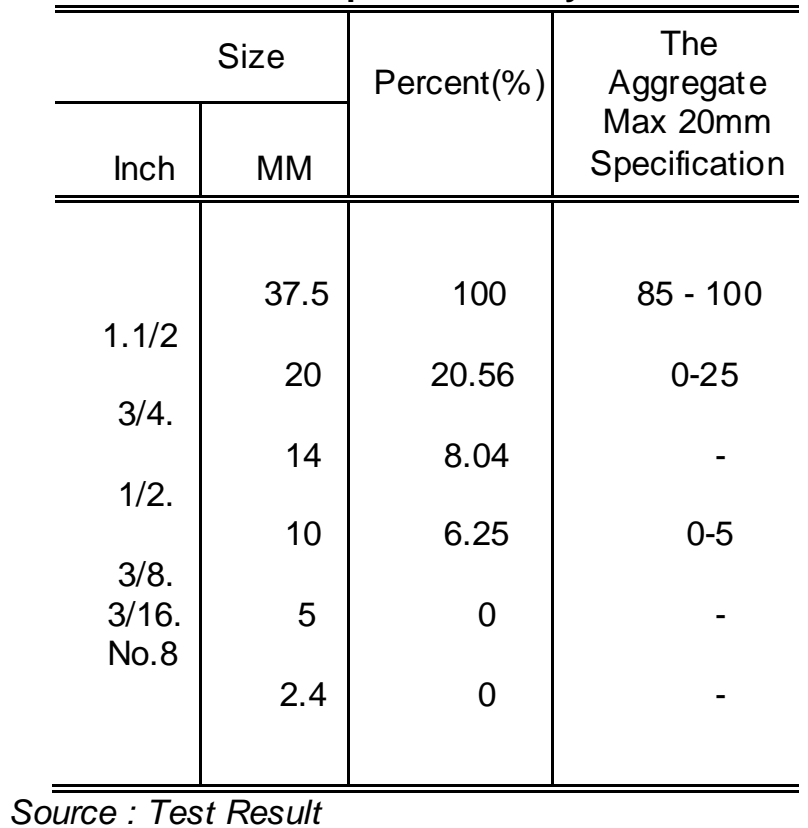

From Table 1. The Wekondo Split Test Analysis Test results above can also be plotted into the graph.

The Experimental Study Of Wekondo Materialsplite And Sand Of Poni-Poniki District Tirawuta East Kolaka Regency As Material Of Concrete Making Mansyur 


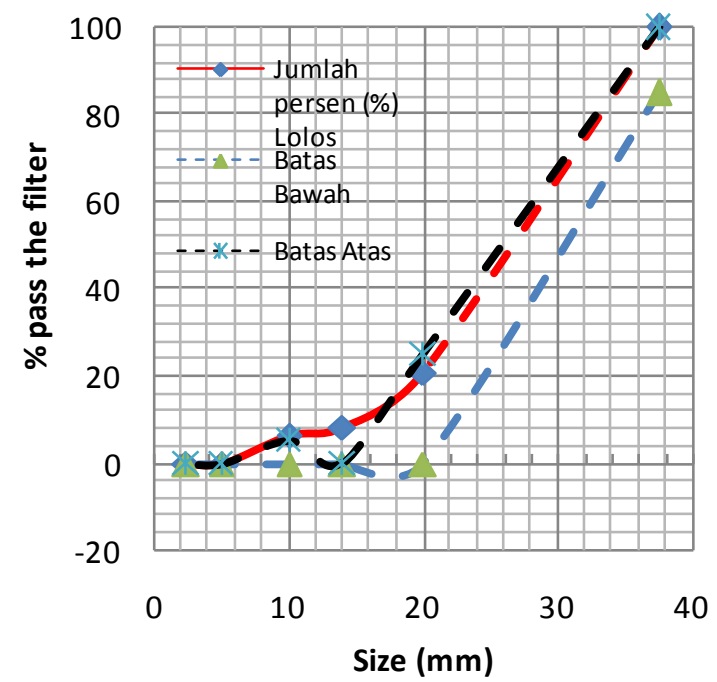

Figure 1. Split Screen Analysis Chart from Wekondo Village

In the table and graph above, it can be seen that on the size of \# 3/8 inch screen, the percentage of pass filter exceeds the specification limit of $6.25 \%$. This only affects the composition of the sand requirement used.

While testing of sieve analysis on Poni-Poniki river sand can be seen in Table 2. Test Result of Poni-Poniki Sand Filter Analysis.

Table 2. Test Result of Poni-Poniki Sand Filter Analysis. Tabel 2. Hasil Uji Analisa

Saringan Pasir Poni-Poniki.

\begin{tabular}{r|r|r|r}
\hline $\begin{array}{r}\text { No \# } \\
\text { (nch) }\end{array}$ & $\begin{array}{r}\text { No \# } \\
(\mathrm{mm})\end{array}$ & $\begin{array}{r}\text { Escaped } \\
\text { Cumulativ } \\
\mathrm{e}\end{array}$ & $\begin{array}{r}\text { Specificatio } \\
\mathrm{n}\end{array}$ \\
\hline \hline $3 / 16$. & 4.8 & 91.03 & $89-100$. \\
\hline$\# 8$ & 2.4 & 79.20 & $60-100$. \\
\hline$\# 16$ & 1.2 & 66.74 & $30-100$. \\
\hline$\# 30$ & 0.6 & 50.04 & $15-100$. \\
\hline$\# 50$ & 0.3 & 28.89 & $5-70$. \\
\hline$\# 100$ & 0.15 & 3.85 & $0-15$ \\
\hline \multicolumn{2}{r|}{ PAN } & 0,00 & 0 \\
\hline \hline
\end{tabular}

Source: Test Result

In Table 2. The Test Results of Pony-Poniki Sand Filter Analysis can be plotted into the tiles in Figure 2. Sieve Analysis on Pony-Poniki Sand.

The Experimental Study Of Wekondo Materialsplite And Sand Of Poni-Poniki District Tirawuta East Kolaka Regency As Material Of Concrete Making

Mansyur 


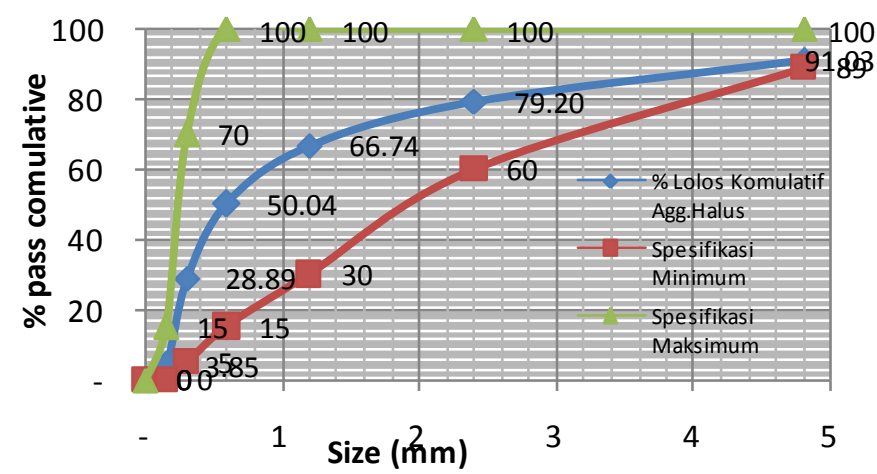

Figure 2. Graph of sand filter analysis from Poni-Poniki river.

In the graph above shows that Pony-Poniki sand is included in the fine aggregate standard specific ation.

Testing Characteristics of Sand Pony-Poniki can be seen in Table 3.

Table 3. Data characteristic of Poni-Poniki Sand test re sults.

\begin{tabular}{c|c|c|c|}
\hline \hline $\begin{array}{c}\text { Fine } \\
\text { aggregate } \\
\text { data } \\
\text { required }\end{array}$ & Results & \multicolumn{2}{|c}{$\begin{array}{c}\text { Standard } \\
\text { Testing } \\
\text { Specificatio } \\
\text { ns }\end{array}$} \\
\cline { 3 - 4 } & & Min & Max \\
\hline \hline $\begin{array}{c}\text { Water } \\
\text { content }\end{array}$ & $0,58 \%$ & - & 5,0 \\
\hline Mud level & $1,68 \%$ & - & 3 \\
\hline $\begin{array}{c}\text { Weight size } \\
\text { SSD }\end{array}$ & $2,661 \%$ & 2,5 & - \\
\hline $\begin{array}{c}\text { Weight } \\
\text { volume }\end{array}$ & $1,81 \mathrm{~kg} / \mathrm{ltr}$ & 1,2 & - \\
\hline Absorption & $1,647 \%$ & 0,2 & 2,0 \\
\hline \hline
\end{tabular}

Source: Test results data at Public Works Laboratory of Southeast Sulawesi Province

From the data characteristic of Pony-Poniki sand above can be said feasible to be used without first treatment. While the data characteristic of Split from Wekondo village can be seen in Table 4.

Table 4. Data characteristic of the re sults of te sting Split Wekondo Village

\begin{tabular}{|c|c|c|c|c|}
\hline \multirow{2}{*}{$\begin{array}{l}\text { Crude } \\
\text { aggregat } \\
\text { e data } \\
\text { required }\end{array}$} & \multirow{2}{*}{$\begin{array}{c}\text { Te } \\
\text { st } \\
\text { Re } \\
\text { sul }\end{array}$} & \multicolumn{2}{|c|}{$\begin{array}{c}\text { Standard } \\
\text { Testing }\end{array}$} & \multirow{2}{*}{$\begin{array}{c}\text { Infor } \\
\text { matio } \\
n\end{array}$} \\
\hline & & Min & Max & \\
\hline $\begin{array}{c}\text { Water } \\
\text { conntent } \\
\text { Mud } \\
\text { level }\end{array}$ & $\begin{array}{l}0, \\
6.3 \\
0, \\
77\end{array}$ & $\overline{0}$ & 2,0 & $\begin{array}{c}\text { Comp } \\
\text { lies } \\
\text { Comp } \\
\text { lies }\end{array}$ \\
\hline
\end{tabular}

The Experimental Study Of Wekondo Materialsplite And Sand Of Poni-Poniki District Tirawuta East Kolaka Regency As Material Of Concrete Making

Mansyur 


\begin{tabular}{|c|c|c|c|c|}
\hline $\begin{array}{c}\text { Weight } \\
\text { size SSD }\end{array}$ & $\begin{array}{l}2 \\
91\end{array}$ & 2,5 & - & $\begin{array}{c}\text { Comp } \\
\text { lies }\end{array}$ \\
\hline $\begin{array}{l}\text { Weight } \\
\text { volume }\end{array}$ & $\begin{array}{l}1, \\
70\end{array}$ & 1,2 & - & $\begin{array}{c}\text { Comp } \\
\text { lies }\end{array}$ \\
\hline $\begin{array}{c}\text { Absorptio } \\
n\end{array}$ & $\begin{array}{c}1, \\
36 \\
\end{array}$ & 0,2 & 4,0 & $\begin{array}{c}\text { Comp } \\
\text { lies }\end{array}$ \\
\hline Wear & $\begin{array}{r}19 \\
.6 \\
\end{array}$ & 0 & 40 & $\begin{array}{c}\text { Comp } \\
\text { lies }\end{array}$ \\
\hline
\end{tabular}

Source: Test results data at Public Works Laboratory of Southeast Sulawesi Province

All characteristics of Split testing meet the specification standard so that it can be used in making concrete.

\section{a. Concrete Pressure Testing}

To know the quality of concrete achieved, concrete compressive strength testing after concrete treatment done periodically by soaking method of test specimen. This study only tested the compressive strength of concrete with 7 days and 28 days' life time. The result of concrete compressive strength can be seen in Table 5.

Table 5. Strong Concrete Pressure Cube

\begin{tabular}{|c|c|c|}
\hline $\begin{array}{c}\text { Planni } \\
\text { ng } \\
\text { Variati } \\
\text { on }\end{array}$ & $\begin{array}{c}\text { Strong } \\
\text { Press } \\
7 \text { Days } \\
\left(\mathrm{Kg} / \mathrm{Cm}^{2}\right)\end{array}$ & $\begin{array}{c}\text { Strong Press } \\
28 \text { Days } \\
\left(\mathrm{Kg} / \mathrm{Cm}^{2}\right)\end{array}$ \\
\hline \multirow{4}{*}{$\begin{array}{c}\text { Concre } \\
\text { te } \\
\text { Normal }\end{array}$} & 195.27 & 249,13 \\
\hline & 215.47 & 249,13 \\
\hline & 202.00 & 262,60 \\
\hline & 202.00 & 269,33 \\
\hline $\begin{array}{c}\text { Avera } \\
\text { ge }\end{array}$ & 203,68 & 257,55 \\
\hline
\end{tabular}

Source: Test results of compressive strength of concrete cube

In Table5. Strong Concrete Pressure The cube can be plotted into a concrete compressive graph as shown in Fig. 3.

Figure 3. Test results of concrete compressive strength

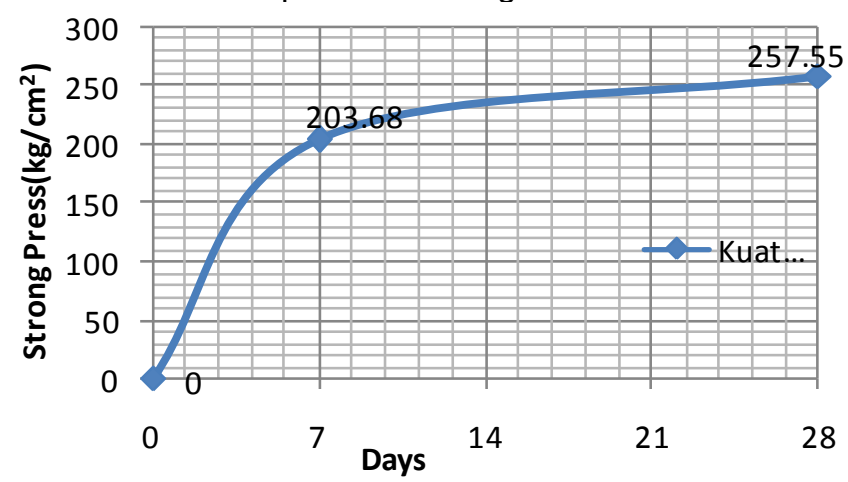

Figure 3. Strong concrete press with sand material Poni-Poniki and Split Wekondo

From the result of compressive strength at age 28 days looks able to exceed $\mathrm{K}$ 250 quality with value $257,55 \mathrm{~kg} / \mathrm{cm} 2$, whereas its mixed formulation is K-250 or

The Experimental Study Of Wekondo Materialsplite And Sand Of Poni-Poniki District Tirawuta East Kolaka Regency As Material Of Concrete Making 
compressive strength $250 \mathrm{~kg} / \mathrm{cm} 2$.

\section{CONCLUSION}

From the research result can be concluded as follows:

1. Testing of Split characteristic from Wekondo and Pasir village from Sungai Poni-Poniki meets the specification standard specified in SNI.

2. Strong Press at the age of 28 days can exceed the quality of K-250 is $257.55 \mathrm{~kg} / \mathrm{cm} 2$ so that, split material from Wekondo and Pasir Village of Poni-Poniki River can be used as normal concrete material making.

\section{SUGGESTION}

For further research, it should try to do research with higher quality concrete design so that it is expected that the material availability can be a reference material with the service of various quality of the desired concrete.

\section{BIBLIOGRAPHY}

Kardiyono. 1992. TeknologiBeton, JurusanTeknik SipilFakultasTeknikUGM.Yogyakarta.

Mulyono, Tri.2003. TeknologiBeton. Andi Ofset.Yogyakarta.

Standar Nasional Indonesia. 1974-2011. Cara Uji Kuat Tekan Beton dengan Benda Uji Silinder Standar Nasional Indonesia. 15-2049-2004. Semen Portland.

Standar Nasional Indonesia. 03-2834-2000. Tata cara pembuatan rencana campuran beton normal.

Tjaronge, M.W. 2012. Semen dan Beton Berongga. Cetakan 1. Telaga Zam-Zam, Makassar. 